\title{
Ocean Sub-Mesoscale Dynamics Research Benefiting from Novel Radar Imaging Technologies
}

\author{
Lingling $\mathrm{Xie}^{1,2^{*}}$ and Xiaomin $\mathrm{Ye}^{3}$ \\ ${ }^{1}$ Guangdong Key Laboratory of Coastal Ocean Variability and Disaster Prediction, Guangdong Ocean University, China \\ ${ }^{2}$ Department of Atmospheric and Oceanic Science, University of Maryland, College Park, USA \\ ${ }^{3}$ National Satellite Ocean Applications Service, State Oceanic Administration, China
}

Submission: July 02, 2017; Published: August 23, 2017

*Corresponding author: Lingling Xie, Department of Atmospheric and Oceanic Science, University of Maryland, USA, Email: 1lingxie@umd.edu

\section{Mini Review}

Sub-mesoscale dynamic processes with spatial scales of $1-200 \mathrm{~km}$ are the key but unwell-known components in the routine of the energy cascade and the enhanced vertical exchange in the ocean [1]. Thus, the sub-mesoscale processes have been hot spots in the research of physical oceanography in recent years [2,3]. However, they are easily missing by shipboard instrument detection. Synthetic aperture radar (SAR) is a novel, high resolution imaging radar. The spatial resolutions of satellite SAR images reach several meters with swath widths as 50$500 \mathrm{~km}$. Therefore, SAR has become a powerful tool for detecting the sub-mesoscale ocean dynamic processes [4-6].

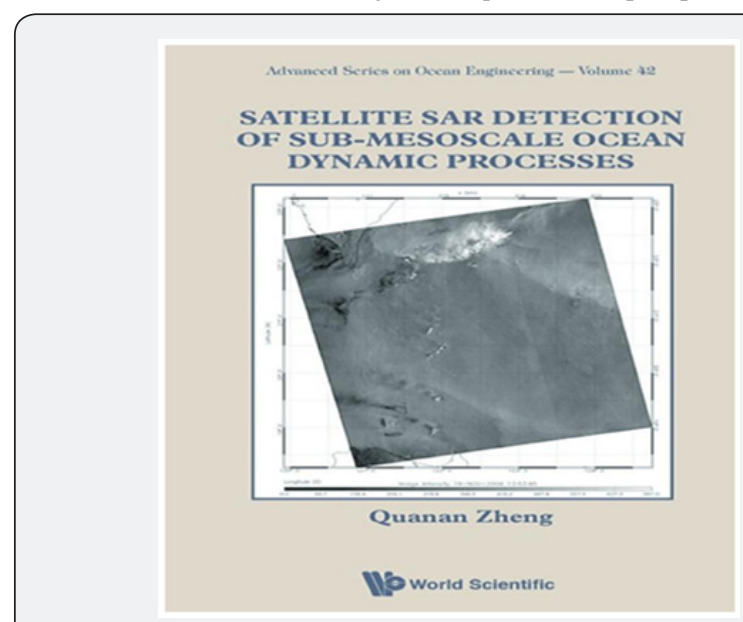

Figure 1: Book Satellite SAR Detection of Sub-mesosale Ocean Dynamic Processes authored by Dr. Quanan Zheng.

The book Satellite SAR Detection of Sub-mesosale Ocean Dynamic Processes (Figure 1), authored by Dr. Quanan Zheng, University of Maryland, College Park, MD, USA, provides updated theories and methods for the use of SAR onboard satellite to detect sub-mesoscale ocean dynamic processes. The author shares the unique research results and experiences in this field, including the physics of SAR detection of the phenomena and the detailed dynamics of these ocean processes. The book contains eleven chapters. For the conveniences of readers with various backgrounds, Chapter 1 provides the fundamentals of radar and SAR detection and the history of space-based SAR used for ocean detection. Chapters 2-7 present theories for SAR imaging and methods for dynamic parameter extraction for the sub-mesoscale ocean vortex train (Chapter 2), spirals on the sea (Chapter 3), ocean near-inertial oscillations (Chapter 4), estuary outflow jet (Chapter 5) and ocean internal waves (Chapters 6-7). Chapters 8-10 are devoted to SAR detection of ocean bottom topography. Finally, Chapter 11 contains interesting results derived from the uses of satellite SARs combined with visible band sensors for detecting the selected air-sea boundary layer processes, such as island-induced atmospheric solitary packets, atmospheric frontal waves and sea surface rainfall [7].

The monograph of Satellite SAR Detection of Sub-mesosale Ocean Dynamic Processes has been published as Advanced Series on Ocean Engineering Volume 44 by World Scientific Publishing Co. Pte. Ltd. (www.worldscientific.com). We believe that reading the book will be enjoyable and helpful for readers, who are engaged in the research and teaching of physical oceanography, satellite oceanography, radar engineering and related subjects.

\section{Acknowledgement}

This work is supported by the National Nature Science Foundation of China under contact No. 41476009 and the Project of Enhancing School with Innovation of Guangdong Ocean University under contact No. GDOU2016050240.

\section{References}

1. McWilliams JC (2016) Submesoscale currents in the ocean, Proceedings of the Royal Society of London A, The Royal Society 472(2189): 20160117.

2. Qiu Bo, Nakano T, Chen S, Klein P (2017) Submesoscale transition from geostrophic flows to internal waves in the northwestern Pacific upper ocean. Nat Commun 8: 14055. 
3. Petrenko A, Doglioli A, Nencioli F, Marion Kersalé, Ziyuan Hu, et al (2017) A review of the LATEX project: mesoscale to submesoscale processes in a coastal environment. Ocean Dynamics 24(3): 513-533.

4. Fu LL, Holt B (1983) Some examples of detection of oceanic mesoscale eddies by the SEASAT synthetic-aperture radar. Journal of Geophysical Research: Oceans 88(C3): 1844-1852.

5. Zheng Q Holt B, Li X, Xinan L, Qing Z, et al. (2012) Deep- water seamount wakes on SEASAT SAR image in the Gulf Stream region. Geophysical Research Letters 39(16): L16604.
6. Karimova S, Gade M (2016) Improved statistics of sub-mesoscale eddies in the Baltic Sea retrieved from SAR imagery. International Journal of Remote Sensing 37(10): 2394-2414.

7. Zheng Q (2017) Satellite SAR Detection of Sub-mesoscale Ocean Dynamic Processes. World Scientific, London, pp. 1-308.
Your next submission with Juniper Publishers will reach you the below assets

- Quality Editorial service

- Swift Peer Review

- Reprints availability

- E-prints Service

- Manuscript Podcast for convenient understanding

- Global attainment for your research

- Manuscript accessibility in different formats

( Pdf, E-pub, Full Text, Audio)

- Unceasing customer service

Track the below URL for one-step submission https://juniperpublishers.com/online-submission.php 